\title{
学級集団における大局的構造特性と児童のモラール
}

\author{
田㠃 敏 昭* 狩 野 素 朗**

\section{MACROSCOPIC CHARACTER OF SOCIOMETRIC STRUCTURE AND SCHOOL MORALES IN THE CLASSROOM}

\author{
Toshiaki TASAKI AND Soro Kano
}

\begin{abstract}
The first purpose of the present study was to propose a measuring procedure of the macroscopic character of sociometric structure deduced from a graph theory called "sociometric condensation model". In this model, the following five dimensions were proposed to identify the macroscopic structure : unity, centralization, polarization, hierarchism and density. The other purpose was to apply this model to classrooms and to investigate the relationship between the macroscopic character and pupils' school morales. Sociometric test and school morale questionaires were given to 31 classes in 5 elementary schools. The relationship between unity, centralization and hierarchism, and school morales was found.
\end{abstract}

Key words: classroom, macro-structure, sociometry, condensation, school morale.

従来, 学級集団については, ソシオメトリック構造の 視点から多くの研究が行われてきた。このソシオメトリ ック的技法による構造把握の方法は, 集団内の人間関係

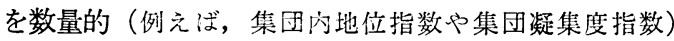
に表現出来ると共に, ソシオグラムとして視覚的にも表 現出来る。このソシオグラムは, 直観的に集団構造を理 解することが出来るといら長所をもつが，それを作製す る際，一定の定形的手法がないので，作図された結果は， 製作者の主観や技術に影響されることが少なくない。 そのため, 場合によっては適切な表示がされず，かえっ てその構造を理解することが出来ないこともある。ま た，集団の構成員が多くなると，それだけ関倸を示す線 の数が多くなり, 線と線が交錯して複雑になるため, 集 団の構造を大局的に把握することが出来にくくなる。

ソシオグラムにおけるこのような難点を解決するため, 狩野 $(1980,1985)$ はグラフ理論におけるコンデンセイ

* 佐賀大学教育学部 (Saga University)

** 九州大学教育学部 (Kyusyu University)
ションの手法を用いて集団の大局的構造をより単純な形 で表現する方法を考案した。

それは，ソシオメトリック構造における相互選択関係 を基準にして成分を構成し，順次凝縮していくやり方で ある。これを, ソシオメトリック・コンデンセイション と呼ぶ。FIG. 1 に例示されたソシオグラムは, この手法 により FIG. 2 のようなソシオメトリック・コンデンセ イションとして表現することができる。ここで，FIG.1 のソシオグラムから FIG. 2 のコンデンセイションにど う凝縮していくかについて簡単に述べてみる。 ステップ 1 ：相互選択関係にある成員たちを全てまと

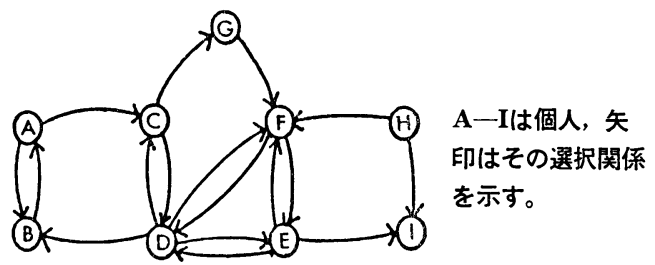

FIG. 1 ソシオグラムの例 


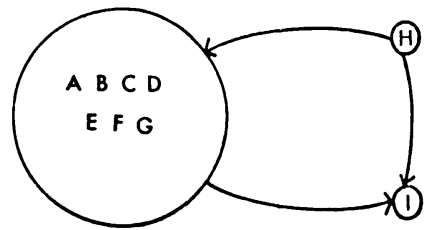

FIG. 2 ソシオメトリック・コンデンセイションの1例 めて，集合 $\left(\mathrm{M}_{1}, \mathrm{M}_{2}\right)$ をつくる。この段階で FIG. 1 の ソシオグラムは FIG.3(a)のようになる。

(a)

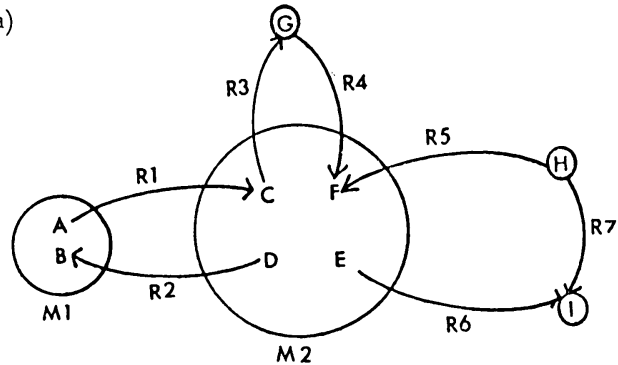

(b)

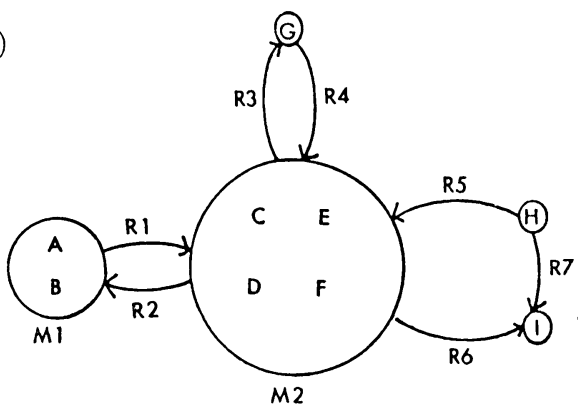

FIG. 3 凝縮の過程

ステップ 2 : 1 つの集合を, 1 人の成員と同様に 1 つ の成分と考えるなら，FIG.3 (a)は FIG.3 (b)のように表 現することができる。 $\mathrm{R}_{1} \sim \mathrm{R}_{7}$ は，本来成員間の選択関 係であるが，集合をつくった場合，集合と集合，集合と 成員なども成分間の関係と見倣すことにする。

ステップ $3: R_{1} \sim R_{7}$ を成分間の関係とすれば, FIG. 3 (b) の $\mathrm{R}_{1}$ と $\mathrm{R}_{2}$ は $\mathrm{M}_{1}$ と $\mathrm{M}_{2}$ の相互選択関係, $\mathrm{R}_{3}$ と $\mathrm{R}_{4}$ は $\mathrm{M}_{2}$ と $\mathrm{G}$ との相互選択関係を示していることに なる。そこで， $\mathrm{M}_{1}$ と $\mathrm{M}_{2}, \mathrm{M}_{2}$ と $\mathrm{G}$ をまと新しい集合 をつくる。こうしてまとめたものが，FIG.2である。こ れ以上は，成分間に相互選択関係がないので，これを最 終的なソシオメトリック・コンデンセイションとする。

このようにして画かれた構造は一様ではなく, さまざ まな特徵をもつ。この構造の特性を記述するため，狩野 (1980，1985） は統合性, 集中性, 階層性, 極性, 稠密 性の 5 次元をあげているが，このうち集団の識別性が高 いのは統合性, 集中性, 階層性なので, 本研究では, こ の 3 つの次元を適用する。
「統合性」とは, 構造を全体としてみたとき, その連 なりの度合いである。学級集団の場合, その学級が全体 として2つあるいはそれ以上に分離していない統合構 造, いくつかのまとまった塊に分離している分団構造等 に区別される (FIG.4(a)(b))。
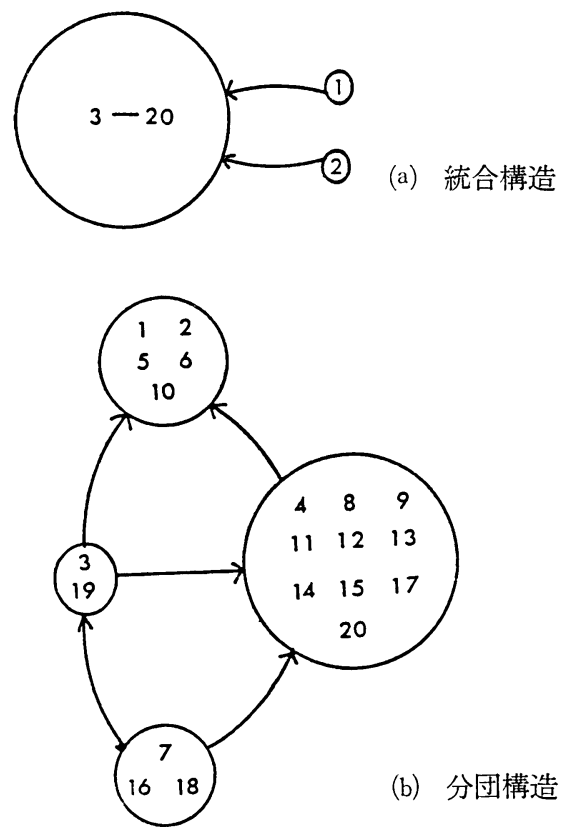

FIG. 4 統合性の例

「集中性」とは, 構造内における中心と周辺の分化の 度合を言うものである。ある 1 つの中心的成分に他の成 分からの選択が集中していれば, それは高集中構造 (FIG. 5 (a)) であり, 中心と周辺の分化が進んでないものは低 集中構造 (FIG.5(b)) である。

「階層性」とは, 組織体におけるフォーマル構造のよ うな階層がどの程度存在するか, の次元である。階層の 分化の度合が強い高階層化構造, 分化の度合が弱い低階 層構造, 階層が存在しない無階層構造などに区分される。

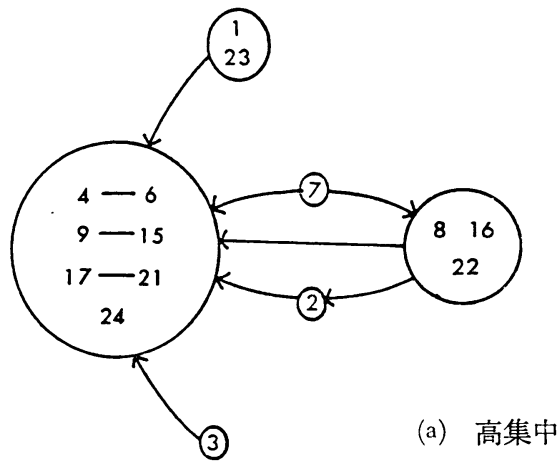




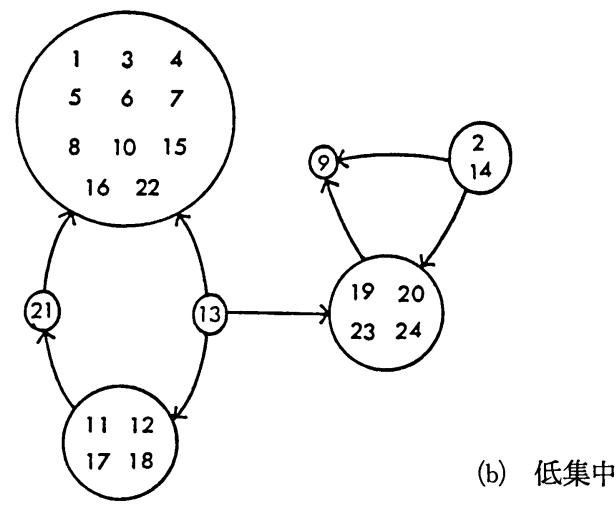

FIG. 5 集中性の例

(FIG. 6(a)(b)(c)) 本研究では階層の有無だけを問題とし た。

このようなソシオメトリック・コンデンセイション は，集団構造の記述方法として，それなりの有用性をも つと思われる。しかし，このような手法によって明らか にされる構造特性の形成過程や, その構造特性が集団及 び集団成員に及ぼす影響などが明らかにされるなら，そ の有用性はさらに増すであろう。本研究は，そうした脈 絡の 1 つとしてコンデンセイションの手法によって学級 集団の構造をとらえ，そこで明らかになる大局的構造の 諸特性と学級成員のモラールとの関係を検討しようとす

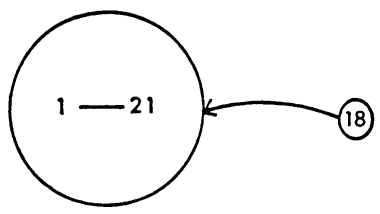

(a) 無階層構造

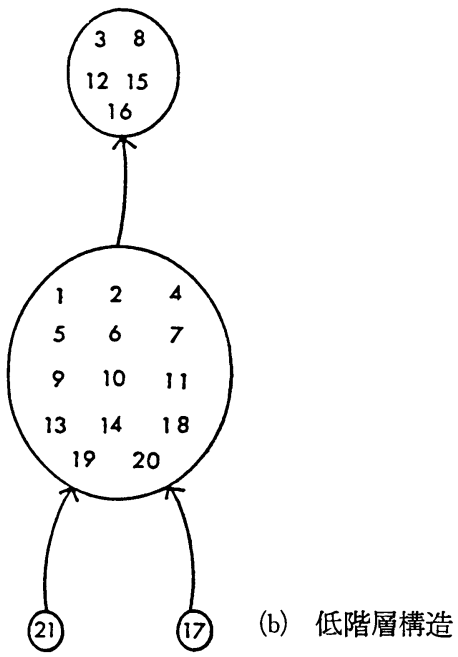

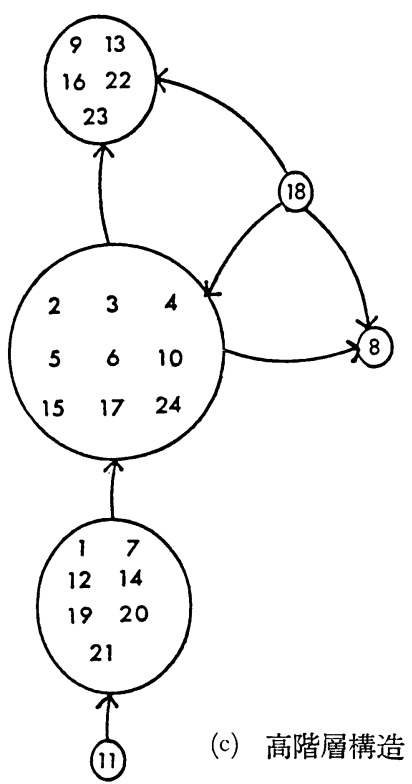

FIG. 6 階層性の例

るものである。

\section{方法}

調査対象 K県下 5 つの小学校 $4,5,6$ 年より, それ ぞれ10学級 342名, 10学級 353名, 11学級344名の計1039 名の児童を調查の対象とした。

調査日時 昭和 58 年 9 月, 10 月。

調査内容 2 種類の質問紙を用意した。1つは, 学級 構造を測定するためのソシオメトリック・テストであり, これは,「学習」および「遊び」を基準にして, 学級の 中からそれぞれ 3 名を選択させた。

も51つは, 児童のモラールを測定する項目 群であ る, これは, 学級の雾囲気, 級友との関係, 学習意欲の サブカテゴリーに分け, SMT, 吉崎(1978), 三隅(1978) などを参考にし，以下に示す 9 つの質問項目により測定 した。

学級の雾囲気 (1)「あなたの組は明るく楽しい組だと 思いますか」，(2)「あなたの組はよくまとまっていると 思いますか」，(3)「あなたの組の人たちは協力的でたす けあっていると思いますか」

級友との関係（4）「あなたの組の人たちはみんなあな たに親切にしてくれますか」，(5)「あなたは，組の人た ちからすかれていると思いますか」，(6)「あなたの組に は，あなたの尊敬する友だちがいますか」

学習意欲 (7)「勉強をしていてわかってくると楽しい と思いますか」，(8)「授業中，先生にあてられるのはす 
きですか」，(9)「もっと勉強してよい成績をとろらと努 カしていますか」

各項目とも 5 段階の選択肢を持ち, 集計にあたっては, positive な反応から negative な反応へ $5 \sim 1$ の得点を 付与した。また 3 つのサブカテゴリー得点を合計して 「総合モラール」とした。

調查の実施 学級担任による集団面接によった。

\section{結果と考察}

学級の構造特性の分類 実際の調査対象は31学級であ ったが，児童数が 10 名以下の小数学級法分析から省い たので，以後は 26 学級が分析の対象となる。また，小 学校中学年以上では, これまでの経験からして, 学級の 中で，男女が混合したインフォーマル集団を形成するこ とは稀であり, 本研究でも, ソシオメトリック・テスト で異性を選択するケース注皆無に近かったので, 1 学級 の中でも男女は別々の集団と見倣すことにした。従っ て, 分析の対象は男, 女それぞれ26集団, 計52集団であ る。

各次元におけるカテゴリーの分類基準について狩野は 別に提唱しているが $(1980,1985)$ ，それはまだ確定的な ものではない。従って，現段階で注，現実の集団を分類 する際，対象となる集団を総合的にみて相対的に分ける 方がより妥当であろう。本研究でも，分析対象となった 52集団を総合的にみて, TABLE 1，に示すような，分
TABLE. 1 各次元における分類カテゴリーと分類基準

\begin{tabular}{|c|c|c|}
\hline 次元 & カテゴリー & 分類基準 \\
\hline \multirow{2}{*}{ 統合性 } & 統 合 & 下位集団の数 1 \\
\hline & 分 団 & 2 以上 \\
\hline \multirow{2}{*}{ 集中性 } & 高集中 & 1 個のコンポネントをとりまく矢の数 5 以上 \\
\hline & 低集中 & 4 以下 \\
\hline \multirow{2}{*}{ 階層性 } & 有階層 & $\begin{array}{l}\text { 一方向に進んでいるコンポネント間の矢の数 } \\
\text { 1以上 }\end{array}$ \\
\hline & 無階層 & $" 1$ \\
\hline
\end{tabular}

類カテゴリー及び分類基準を設定した。

構造特性と児童のモラール TABLE 2, TABLE 3,

TABLE 4 は, 各次元ごとに TABLE 1 の基準によって 集団を分け, 男女別, 選択基準別に各群俍当する学級 児童のモラールの平均値を比較したものである。

統合性次元の場合, 選択基準が「遊び」において，男 子では, 統合構造群の児童の「総合モラール」は, 分団 構造群の児童よりその平均值が高く,「学級の雾囲気」, 「学習意欲」などにおいても前者が後者より高い。しか し，女子では，逆に分団構造群の児童の方が，「学級の 雾囲気」,「級友との関係」（差の傾向）などにおいて 児童より平均值が高くなっている。

集中性次元では, 選択基準が「学習」において, 男子 の高集中構造群の児童は低集中構造群の児童より「学習 意欲」の平均值が高い。選択基準が「遊び」の場合, 男

TABLE 2 統合性の違いと児童のモラール

\begin{tabular}{|c|c|c|c|c|c|c|c|c|c|}
\hline \multirow{3}{*}{$\begin{array}{l}\text { 热 択 } \\
\text { 綂 合 }\end{array}$} & 集 & & & $i$ & & & 焦 & 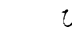 & \\
\hline & \multirow[b]{2}{*}{ 性 } & \multicolumn{2}{|c|}{ 男 } & \multicolumn{2}{|c|}{ 女 } & \multicolumn{2}{|c|}{ 男 } & \multicolumn{2}{|c|}{ 女 } \\
\hline & & 統合 & 分団 & 統合 & 分团 & 統公 & 分団 & 統令 & 分団 \\
\hline \multicolumn{2}{|c|}{ 皃童数(集団数) } & $307(1 i)$ & $160(9)$ & 266(15) & $229(11)$ & $271(15)$ & $196(11)$ & 185111 & $307(16)$ \\
\hline \multirow{3}{*}{$\begin{array}{l}\text { 学級の } \\
\text { 芬四公 }\end{array}$} & $\bar{X}$ & -10.2 & 10.4 & 10.4 & 10.4 & 10.5 & 9.9 & 10.2 & 10.6 \\
\hline & S.D & 2.3 & 2.2 & 2.1 & 2.0 & 2.0 & 2.5 & 2.0 & 2.1 \\
\hline & $t$-test & \multicolumn{2}{|c|}{ n.s. : } & \multicolumn{2}{|c|}{ n.s. } & \multicolumn{2}{|c|}{$\mathrm{p}<.01$} & \multicolumn{2}{|c|}{$\mathrm{p}<.05$} \\
\hline \multirow{3}{*}{$\begin{array}{l}\text { 被友との } \\
\text { 関 係 }\end{array}$} & $\bar{X}$ & 9.7 & 9.4 & 9.8 & 9.9 & 9.6 & 9.5 & 9.7 & 10.0 \\
\hline & S.D & 2.3 & 2.1 & 1.9 & 1.9 & 2.0 & 3.5 & 1.9 & 1.8 \\
\hline & $t-t e s t$ & \multicolumn{2}{|c|}{ n.s. } & \multicolumn{2}{|c|}{ n.s. } & \multicolumn{2}{|c|}{ n.s. } & \multicolumn{2}{|c|}{$\mathrm{p}<.10$} \\
\hline \multirow{3}{*}{ 学䐗意欲 } & $\bar{X}$ & 11.2 & 10.8 & 11.1 & 11.3 & 11.4 & 10.5 & 11.2 & 11.2 \\
\hline & S.D & 2.2 & 2.3 & 2.0 & 1.9 & 2.1 & 2.4 & 1.8 & 2.0 \\
\hline & $\mathrm{t}$-test & \multicolumn{2}{|c|}{$\mathrm{p}<.10$} & \multicolumn{2}{|c|}{ n.s. } & \multicolumn{2}{|c|}{$\mathrm{p}<.01$} & \multicolumn{2}{|c|}{ n.s. } \\
\hline \multirow{3}{*}{$\begin{array}{l}\text { 総 合 } \\
\text { モテール }\end{array}$} & $\bar{X}$ & 31.1 & 30.7 & 31.5 & 31.6 & 31.7 & 30.0 & 31.1 & 31.8 \\
\hline & S.D & 5.3 & 5.2 & 4.8 & 4.6 & 4.6 & 5.9 & 4.5 & 4.8 \\
\hline & $t$-test & \multicolumn{2}{|c|}{ n.s. } & \multicolumn{2}{|c|}{ n.s. } & \multicolumn{2}{|c|}{$p<.01$} & \multicolumn{2}{|c|}{ n.s. } \\
\hline
\end{tabular}


田㠃・狩野：学級集団における大局的構造特性と児童のモラール

TABLE 3 集中性の違いと児童のモラールの平均

\begin{tabular}{|c|c|c|c|c|c|c|c|c|c|}
\hline \multirow{3}{*}{ 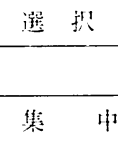 } & 㴶 & & & & & & is & $i$ & \\
\hline & \multirow[b]{2}{*}{ 性 } & \multicolumn{2}{|c|}{ 男 } & \multicolumn{2}{|c|}{ 尖 } & \multicolumn{2}{|c|}{ 罗 } & \multicolumn{2}{|c|}{ 炎 } \\
\hline & & 高 & 低 & 渖 & 低 & 高 & 低 & in & 低 \\
\hline \multicolumn{2}{|c|}{ 児童数（学:䑥数） } & $325(18)$ & $142(8)$ & $77(4)$ & $318(22)$ & $217(12)$ & $250(14)$ & $42(3)$ & $45322)$ \\
\hline \multirow{3}{*}{ 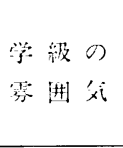 } & $\bar{X}$ & 10.3 & 10.2 & 10.3 & 10.5 & 10.5 & 10.0 & 9.4 & 9.7 \\
\hline & S.D & 2.3 & 2.1 & 2.0 & 2.0 & 2.3 & 2.2 & 1.6 & 3.4 \\
\hline & $\mathrm{t}$-test & \multicolumn{2}{|c|}{ n.s. } & \multicolumn{2}{|c|}{ n.s. } & \multicolumn{2}{|c|}{$p<.05$} & \multicolumn{2}{|c|}{ n.s. } \\
\hline \multirow{3}{*}{$\begin{array}{l}\text { 敨友との } \\
\text { 関 倸 }\end{array}$} & $\overline{\mathrm{X}}$ & 9.6 & 9.4 & 9.7 & 9.9 & 9.8 & 9.4 & 9.8 & 9.1 \\
\hline & S.D & 2.3 & 2.0 & 1.9 & 1.8 & 2.3 & 2.2 & 1.9 & 3.2 \\
\hline & $t$-test & \multicolumn{2}{|c|}{ n.s. } & \multicolumn{2}{|c|}{ n.s. } & \multicolumn{2}{|c|}{$\mathrm{p}<.10$} & \multicolumn{2}{|c|}{ n.s. } \\
\hline \multirow{3}{*}{ 学習意欲 } & $\mathrm{X}$ & 11.2 & 10.7 & 11.3 & 11.1 & 11.2 & 11.0 & 9.9 & 10.4 \\
\hline & S.D & 2.3 & 2.0 & 1.7 & 1.1 & 2.3 & 2.3 & 2.1 & 3.2 \\
\hline & $\mathrm{t}$-test & \multicolumn{2}{|c|}{$\mathrm{p}<.05$} & \multicolumn{2}{|c|}{ n.s. } & \multicolumn{2}{|c|}{ n.s. } & \multicolumn{2}{|c|}{ n.s. } \\
\hline \multirow{3}{*}{ 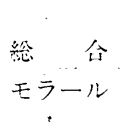 } & $\bar{X}$ & 31.2 & 30.5 & 31.4 & 31.7 & 31.6 & 30.5 & 29.1 & 29.3 \\
\hline & S.D & 5.6 & 4.3 & 4.4 & 4.8 & 5.4 & 5.0 & 4.5 & 9.6 \\
\hline & $t$-test & \multicolumn{2}{|c|}{ n.s. } & \multicolumn{2}{|c|}{ n.s. } & \multicolumn{2}{|c|}{$p<.05$} & \multicolumn{2}{|c|}{ n.s: } \\
\hline
\end{tabular}

子において高集中構造群の坚童の「総合モラール」,「学 級の雾囲気」、「級友との関係」の平均值は, 低集中構造
群の児童の平均值より有意汇高い（学級の雾国気の埸合 は差の傾向）。

TABLE 4 階層性と児童のモラールの平均

\begin{tabular}{|c|c|c|c|c|c|c|c|c|c|}
\hline \multicolumn{2}{|c|}{ 選 択 基 潗 } & \multicolumn{2}{|c|}{ 学 } & \multicolumn{2}{|c|}{ 菭 } & \multicolumn{2}{|c|}{ 游 } & \multicolumn{2}{|c|}{ び } \\
\hline & & \multicolumn{2}{|c|}{ 男 } & \multicolumn{2}{|c|}{ 女 } & \multicolumn{2}{|c|}{ 男 } & \multicolumn{2}{|c|}{ 女 } \\
\hline 階層 & 住 & 有 & 無 & 有 & 無 & 有 & 潶 & 有 & 彗 \\
\hline \multicolumn{2}{|c|}{ 児童数(学級数) } & $217(11)$ & $250(15)$ & $166(8)$ & $329(18)$ & $212(i 2)$ & $255(14)$ & $73(4)$ & $42202)$ \\
\hline \multirow{3}{*}{$\begin{array}{l}\text { 学級の } \\
\text { 雼囲気 }\end{array}$} & $\mathrm{X}$ & 10.0 & 10.4 & 10.6 & 10.3 & 10.5 & 10.0 & 11.0 & 10.3 \\
\hline & S.D & 2.4 & 2.1 & 2.1 & 2.0 & 2.3 & 2.2 & 1.8 & 2.1 \\
\hline & $t$-test & \multicolumn{2}{|c|}{$\mathrm{p}<.10$} & \multicolumn{2}{|c|}{ n.s. } & \multicolumn{2}{|c|}{$\mathrm{p}<.05$} & \multicolumn{2}{|c|}{$\mathrm{p}<.01$} \\
\hline \multirow{3}{*}{$\begin{array}{l}\text { 媇友との } \\
\text { 関係 }\end{array}$} & $\overline{\mathrm{X}}$ & 9.4 & 9.4 & 10.0 & 9.8 & 9.7 & 9.5 & 10.4 & 9.7 \\
\hline & S.D & 2.5 & 1.9 & 1.9 & 1.9 & 2.2 & 2.2 & 1.6 & 1.9 \\
\hline & $t$-test & \multicolumn{2}{|c|}{ n.s. } & \multicolumn{2}{|c|}{ n.s. } & \multicolumn{2}{|c|}{ n.s. } & \multicolumn{2}{|c|}{$\mathrm{p}<.01$} \\
\hline \multirow{3}{*}{ 学腈意欲 } & $\bar{X}$ & 10.8 & 11.3 & 11.5 & 11.1 & 11.1 & 11.0 & 11.3 & 11.2 \\
\hline & S.D & 2.4 & 2.0 & 1.8 & 1.0 & 2.3 & 2.1 & 1.7 & 1.3 \\
\hline & t-test & \multicolumn{2}{|c|}{$p<.05$} & \multicolumn{2}{|c|}{$p<.01$} & \multicolumn{2}{|c|}{ n.s. } & \multicolumn{2}{|c|}{ n.s. } \\
\hline \multirow{3}{*}{$\begin{array}{l}\text { 総 } \\
\text { モラール }\end{array}$} & $\bar{X}$ & 30.3 & 31.6 & 32.1 & 31.0 & 31.4 & 30.6 & 32.1 & 31.0 \\
\hline & S.D & 5.9 & 4.5 & 4.4 & 4.8 & 5.6 & 4.9 & 4.4 & 4.8 \\
\hline & $t$-test & \multicolumn{2}{|c|}{$\mathrm{p}<.01$} & \multicolumn{2}{|c|}{$p<.05$} & \multicolumn{2}{|c|}{$\mathrm{p}<.10$} & \multicolumn{2}{|c|}{$p<.05$} \\
\hline
\end{tabular}

階層性次元では，選択基準が「学習」の場合，男子に おいては「学習意欲」「「総合モラール」において, 無階 層構造群の児童の平均值が有階層樥造群の児童のそれよ り高い。しかし，女子は，男子とは逆の結果である。
一方，選択基準が「遊び」の場合，「学級の雾囲気」 では男女共,「級友との関係」「総合モラール」では女 子において, 有階層構造群の児童の平均值が, 無階層構 造群児童の平均值より有意に高い。 
以上の結果より構造とモラールとの関連を総合的にみ ると, 男子集団の場合, 分団構造より統合構造において, また低集中構造よりも高集中構造の学級において児童の モラールは高いと言える。この傾向は, 選択基準が「遊 び」の場合より顕著である。また,「遊び」の場合に限 って, 有階層構造群の児童のモラールは無階層構造群の 児童のモラールより高い傾向もみられる。こうした結果 は, 対象が小学校高学年であったということに依存する ものと考えられる。この年龄の頃からの男子は，1 つの 課題を達成するために徒党を組もらとする。人と人との 結合には単に「好き」とか「快」とかいら情緒ではなく， 何かを一緒にやりたい, やるとおむしろいといった課題 志向的気持の方が高揚する。徒党は，人が集まっている というのではなく,リーダーの下に結集するといった形 を好むのである。従って，学級もそうした欲求をより満 たす構造, つまり, 統合, 高集中, 有階層といった集団 においてモラールが高くなっていると考察できる。

一方, 女子においては, ある特定の個人に勢力が集中 した集団は好まない。2 2 人, $3 \sim 4$ 人の心の通い合
った関係の中で過ごすことを好む傾向，つまり親和志向 的特性にある。従って男子ほど顕著ではないが，上り分 団構造群においてモラールが高いと考えられる。階層性 次元において, 有階層群の児童のモラールは無階層群の 児童のモラールより高いが，これも，年龄集団の特性と いう点から考えるなら，階層が存在するというより，階 層を可能にする小集団に満足しているのではないかと推 察される。

\section{引用文献}

狩野素朗 1980 集団の大局的構造特性とソシオメトリ ック・コンデンスェイション 九州大学教育学部紀 要, 24 巻 2 号, $13-23$.

狩野素朗 1985 コンデンスェイション法による大局的 集団構造特性の集約 実験社会心理学研究, 24 巻 2 号 (印刷中)

三隅二不二 1978 リーダーシップの行動科学 有斐閣 吉崎静夫 1978 教師のリーダーシップと学級の勢力構 造に関する研究 心理学研究, 49巻, 22-29.

(1985年 2 月 1 日受稿) 